\title{
Fecal Coliforms and Total Coliforms Removal in Water Using Radio-Frequency (RF) Plasma System
}

\author{
Reni Desmiarti ${ }^{1}$, Ariadi Hazmi ${ }^{2} \&$ Yenni Trianda ${ }^{2}$ \\ ${ }^{1}$ Department of Chemical Engineering, Bung Hatta University, Indonesia \\ ${ }^{2}$ Department of Electrical Engineering, Andalas University, Indonesia \\ Correspondence: Reni Desmiarti, Department of Chemical Engineering, Bung Hatta University, Jl. Gajah Mada \\ No. 19, Padang, 25142, Indonesia. E-mail: renitk@bunghatta.ac.id/desmiarti@yahoo.com
}

Received: May 4, 2015

Accepted: June 5, 2015

Online Published: June 30, 2015

doi: $10.5539 /$ mas.v9n $7 \mathrm{p} 80$

URL: http://dx.doi.org/10.5539/mas.v9n7p80

\begin{abstract}
A radio-frequency plasma system (RF) was used to investigate the removal of microorganisms from water. Plasma generated by RF radiation can produce active compounds $\left(\mathrm{H} \bullet, \bullet \mathrm{OH}, \mathrm{H}_{2} \mathrm{O}_{2}, \mathrm{O}_{3}\right.$, etc. $)$ that have a high oxidation potential and can kill microorganisms present in water (fecal coliforms and total coliforms). The frequency of the plasma system was set to 3.0, 3.3 and 3.7 $\mathrm{MHz}$ and applied to river water for 60 minutes. The results show that in all runs, the $\mathrm{pH}$ of the water produced was in the range from 7.4 to 7.9. The removal efficiencies of fecal coliforms achieved were between 83.75 and $95 \%$ and were higher than the removal efficiencies of total coliforms, which were between 82.61 and $93.48 \%$. Meanwhile, the death rate $\left(k_{D}\right)$ of fecal coliforms wasfaster than that of total coliforms. Therefore, the removal of total coliforms is the key to removing microorganisms fromwater. RF plasma treatment can be used for treatment of drinking water to decrease microorganisms.
\end{abstract}

Keywords: radio-frequency, active compounds, microorganisms, water treatment

\section{Introduction}

Industrial, domestic and other activities can have a negative impact on water resources, such as causing a decrease in water quality. Such conditions can cause disruption, damage and danger to living organisms that depend on those water resources. Data from the National Development Planning Agency Indonesia in 2014 indicate that about $65-72 \%$ of contaminated wells were polluted by Escherichia coli. The bacteria come from toilets near the wells and even most of the rivers in Indonesia are contaminated by Escherichia coli. In Permenkes (Ministry of Health Regulation) 492 from 2010 about drinking water quality requirements it is determined that in water that will be used as drinking water, the total coliforms and fecal coliforms should be zero. Accordingly, research about the removal of microorganisms (fecal coliforms and total coliforms) from water is very important.

Water treatment using a plasma system is one of the ways to produce potable water in terms of health aspects. Plasma in water will generate active species, such as $\bullet \mathrm{OH}, \mathrm{H} \bullet, \mathrm{O}_{3}$ and $\mathrm{H}_{2} \mathrm{O}_{2}$. These active species have a high oxidation potential and are able to kill microorganisms and degrade organic compounds in water (Sun et al., 1997). Another advantage of plasma systems is that they can produce ultraviolet light and shockwaves, which can also kill microorganismss in water (Robinson et al., 1973).

Over the last number of years, several researches have been done concerning the reduction of microorganisms in water using plasma systems (Joshi, 1995; Lukes, 2001; Aragi 2009; Desmiarti et al., 2013; Hazmi et al., 2013). Aragi (2009) examined removal efficiency of macroorganisms at $100 \%$ using a corona discharge to generate plasma in the treatment of drinking water. Studies have been devoted to the removal of microorganisms from drinking water by using a pulsed high voltage (Hazmi et al., 2013) or by using a dielectric barrier discharge (Desmiarti et al., 2013). The present research was conducted to investigate the capability of a radio-frequency (RF) plasma system to eliminate microorganisms from riverwater. Experiments were carried out in a batch system to see the effect of frequency on the removal of microorganisms (fecal coliforms and total coliforms). The quality of the water produced was compared with that of water produced by a drinking water refill station (DAMIU) in Padang City, West Sumatra, Indonesia. 


\section{Method}

\subsection{Water Source}

Water samples were taken from the Kuranji River in Padang City, West Sumatra, Indonesia, on 15 April 2014 at 10:00 am under brightweather conditions. This river is one of the water sources for the Regional Water Utility Company (PDAM) in Padang City. The quality of the river water at the sampling time is shown in Table 1.

Table 1. Sample Quality

\begin{tabular}{lcr}
\hline Water Quality Parameter & Unit & Sample \\
\hline $\mathrm{pH}$ & & 7.27 \\
Turbidity & $\mathrm{NTU}$ & 67.6 \\
$\mathrm{TDS}$ & $\mathrm{mg} / \mathrm{L}$ & 404 \\
ORP & $\mathrm{mV}$ & -219.1 \\
Temperature & ${ }^{\circ} \mathrm{C}$ & 30.1 \\
Fecal Coliforms & $\mathrm{MPN} / 100 \mathrm{~mL}$ & 8,000 \\
Total Coliforms & $\mathrm{MPN} / 100 \mathrm{~mL}$ & 23,000 \\
\hline
\end{tabular}

\subsection{Experiment}

The experimental set-up of the radio-frequency plasma system is diplayed in Figure 1.The water samples enter the plasma reactor, made of glass with a thickness of $2 \mathrm{~mm}$ and with a copper wire of $1 \mathrm{~mm}$ thickness and $30 \mathrm{~cm}$ length twisted around it. The electricity generated by the RF plasma generator is channeled through the copper wire to produce a dielectric discharge. This discharge dissociates the water molecules to generate active species thatare capable of killing microorganisms.

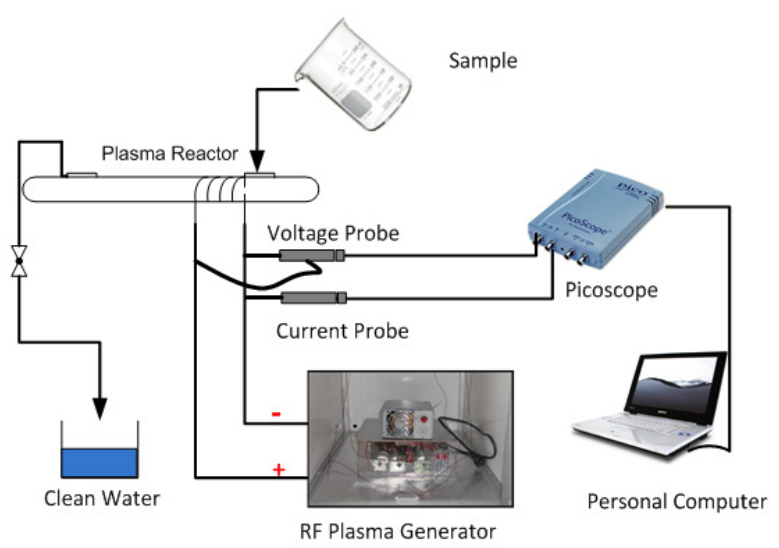

Figure 1. Experimental Set-up of Batch Radio-Frequency (RF) Plasma System

\subsection{Analysis}

The products were analyzed by examining the number of microorganisms (fecal coliforms and total coliforms). The procedure was executed with three different frequencies: 3.0, 3.3 and 3.7 MHz. Analysis of microorganisms (fecal coliforms and total coliforms) was conducted using the most probable number (MPN) method. The MPN method is a serial dilution test using a liquid medium, in this case brilliant green lactose bile $2 \%$ (BGLB) broth, in a test tube to obtain quantitative data about the presence of microorganisms in units of MPN $/ 100 \mathrm{~mL}$.Analysis of water quality parameters was conducted by measuring $\mathrm{pH}$, oxidation and reduction potential (ORP) of samples and products using Martini Instruments tools.

\subsection{Death Rate Calculation}

The death rate of microorganisms was calculated using the first order equation, as follows:

$$
\frac{d N}{d t}=-k N
$$

where $\mathrm{N}$ is the number of microorganisms (MPN/100mL), $\mathrm{t}$ is time $(\mathrm{h})$, and $k$ is microorganisms death constant 
$\left(\mathrm{h}^{-1}\right)$. The $k$ value was calculated by plotting the value of $\ln \left(\mathrm{N} / \mathrm{N}_{0}\right)$ versus $\mathrm{t}$ using the following equation:

$$
\ln \frac{\mathrm{N}}{\mathrm{No}}=-k t
$$

With $\mathrm{N}_{0}$ as the initial number of microorganisms.

\section{Results}

\subsection{Frequency Effect on Removal Efficiency (RE) of Microorganisms}

The effect of the RF plasma system's frequency on the removal of microorganisms can be seen in Figure 2 .

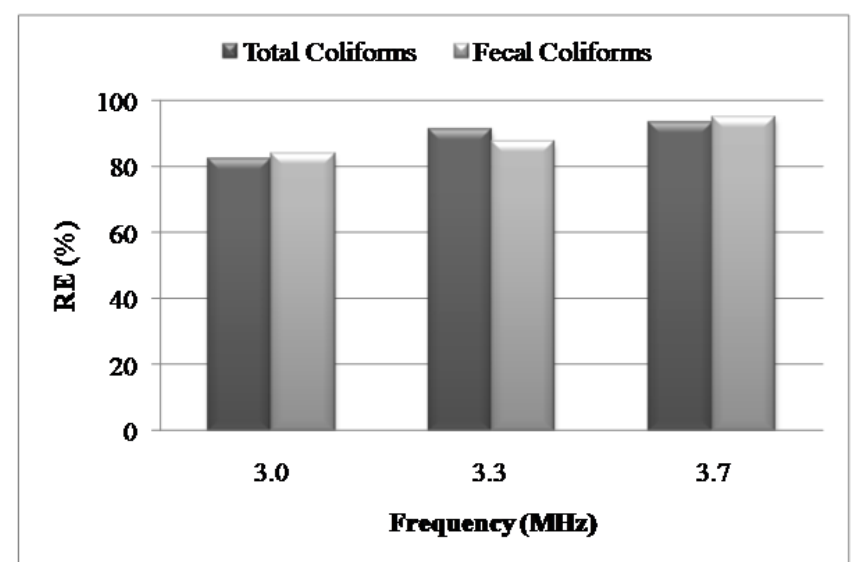

Figure 2. Frequency Effect on Microorganismss Removal

Based on Figure 2 the efficiency of microorganisms removal (fecal coliforms and total coliforms) increased along with the increase of the RF plasma system's frequency. A frequency of $3.0 \mathrm{MHz}$ applied to the sample for 60 minutes could eliminate fecal coliforms and total coliforms by $83.75 \%$ and $82.61 \%$. Meanwhile, at $3.3 \mathrm{MHz}$ the removal efficiency of fecal coliforms and total coliforms increased to $87.5 \%$ and $91.3 \%$, respectively. Increasing the frequency to $3.7 \mathrm{MHz}$ gave a removal efficiency of fecal coliforms and total coliforms of $95.0 \%$ and $93.48 \%$, respectively.

\subsection{Frequency Effect on $\mathrm{pH}$ and $\mathrm{ORP}$}

The effect of frequency on $\mathrm{pH}$ and ORP can be seen in Figure 3.The results show that varying the frequency of the RF plasma system did not significantly affect $\mathrm{pH}$. The $\mathrm{pH}$ values were in the range from 7.3 to 7.9 - still within the quality standards (Figure 3a).An increase of the generated plasma frequency increased the value of ORP, as shown in Figure 3b. According to Suslow (2004), the ORP value indicates the system's ability to perform reduction and oxidation reactions and can be used to monitor the content of microorganismss in the water. The higher the water's ORP value, the more facile oxidation reactions proceed and the higher the amount of damaged cell membranes, so that the water quality increases.

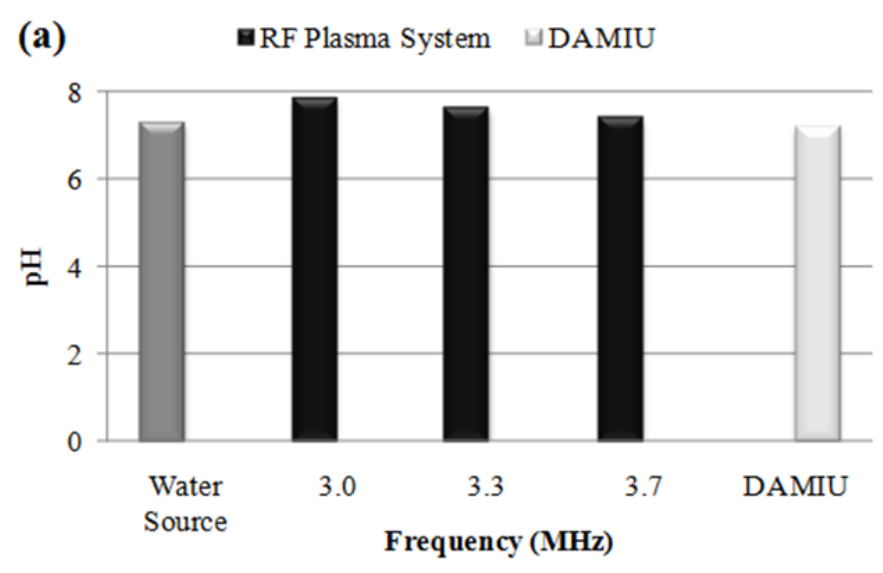




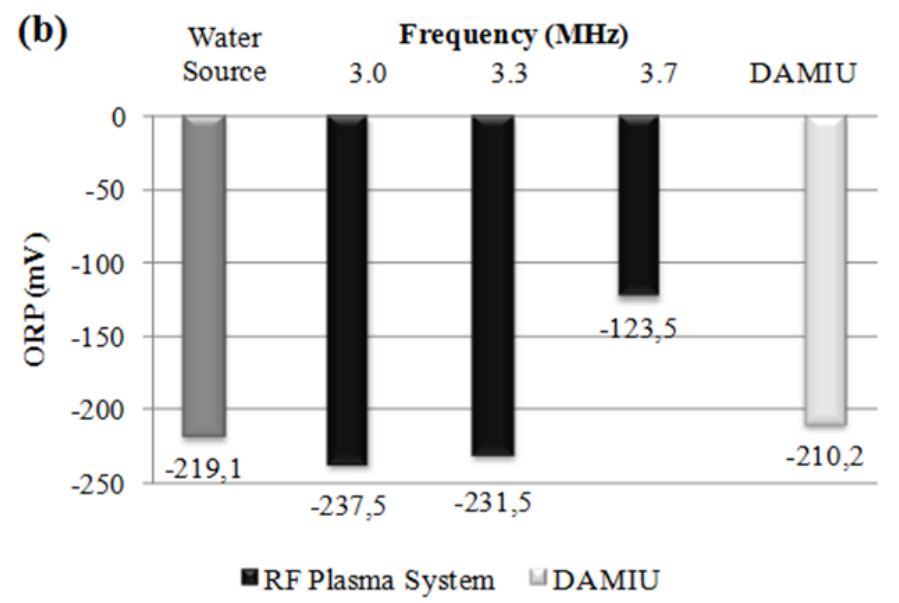

Figure 3. Frequency Effect on $\mathrm{pH}(\mathrm{a})$ and ORP (b)

\section{Discussion}

Increasing the applied voltage also increases the production of active species, such as $\bullet \mathrm{OH}, \mathrm{H} \bullet, \mathrm{O}_{3}$ and $\mathrm{H}_{2} \mathrm{O}_{2}$. This is consistent with the theory that a higher frequency will increase the efficiency of microorganisms removal (fecal coliforms and total coliforms).These active species kill microorganisms by means of electroporation, which perforates the cell membrane due to the influence of an electric charge by ions and electrons, resulting in deactivation of the microorganisms. In addition, the generated active species degrade DNA so that fecal coliforms and total coliforms become inactive (Heesch et al., 2000). A comparison of removal efficiency from the present study with that of other studies is displayed in Table 2. One disadvantage of the DBD and PHV plasma system is that the electrodes are in direct contact with the water, which causes scale build-up on the surface of the electrodes.

To better understand the removal of microorganisms from water, the death rate of total coliforms and fecal coliforms was calculated using Equation 2. The results are shown in Table 3. The highest death rate of microorganisms was at $3.7 \mathrm{MHz}$ with a $k_{D}$ value of $3.00 \mathrm{~h}^{-1}$ for fecal coliforms, i.e. $9 \%$ faster than that of total coliforms $\left(2.73 \mathrm{~h}^{-1}\right)$. This means that the removal of total coliforms is the key to remove microorganisms from water.

Table 2. Comparison of removal efficiency with other studies

\begin{tabular}{llcl}
\hline Authors & Removal Efficiency & $\begin{array}{c}\text { Processing time } \\
\text { (minutes) }\end{array}$ & Plasma System \\
\hline Aragi et al., 2009 & Fecal Coliforms: 100\% & 60 & $\begin{array}{l}\text { Dielectric Barrier Discharge } \\
\text { (DBD) }\end{array}$ \\
Hazmi et al., 2013 & $\begin{array}{l}\text { Fecal Coliforms: } 25-100 \% \\
\text { Total Coliforms: } 40-100 \%\end{array}$ & 60 & $\begin{array}{l}\text { Pulsed High Voltage (PHV) at } \\
\text { 5-10 kV }\end{array}$ \\
Desmiarti et al., 2013 & $\begin{array}{l}\text { Fecal Coliforms: } 88-95 \% \\
\text { Total Coliforms: } 95-98 \%\end{array}$ & 60 & $\begin{array}{l}\text { Dielectric Barrier Discharge } \\
\text { (DBD)at 10-13 kV }\end{array}$ \\
This study & $\begin{array}{l}\text { Fecal Coliforms: } 84-95 \% \\
\text { Total Coliforms: 83-93\% }\end{array}$ & 60 & Radio Frequency at 3-3.7 MHz \\
\hline
\end{tabular}

Table 3. Microorganisms Death Constant $\left(k_{\mathrm{D}}\right)$

\begin{tabular}{lll}
\hline \multirow{2}{*}{ Frequency $(\mathrm{MHz})$} & \multicolumn{2}{c}{$k_{\mathrm{D}}\left(\mathrm{h}^{-1}\right)$} \\
& Fecal Coliforms & Total Coliforms \\
\hline 3.0 & 1.82 & 1.75 \\
3.3 & 2.08 & 2.44 \\
3.7 & 3.00 & 2.73 \\
\hline
\end{tabular}


A comparison ofthe qualities of water produced by the RF plasma system and water produced through common ultraviolet systems from drinking water refill stations in Indonesia (DAMIU) can be seen in Table 4. From the water quality of the produced water it can be seen that water generated by the RF plasma system, although no pretreatment process was applied, nearly had the same quality as water produced with an ultraviolet treatment system that did use a pretreatment process. These results indicate that the RF plasma system is capable of producing potable water.

The ability of the RF plasma system to eliminate microorganisms in water makes this plasma technology a viable alternative for drinking water treatment in the future to produce potable water with aquality in accordance with health standards.

Table 4. Comparison of RF Plasma System with UV System in DAMIU

\begin{tabular}{lcrrr}
\hline $\begin{array}{c}\text { Water Quality } \\
\text { Parameter }\end{array}$ & Unit & Sample & $\begin{array}{c}\text { Sistem Plasma RF } \\
\text { (Frequency of 3.7 MHz) }\end{array}$ & $\begin{array}{c}\text { Sistem UV } \\
\text { (from DAMIU) }\end{array}$ \\
\hline $\mathrm{pH}$ & & 7.27 & 7.39 & 7.21 \\
Turbidity & $\mathrm{NTU}$ & 67.6 & 65.1 & 66 \\
$\mathrm{TDS}$ & $\mathrm{mg} / \mathrm{L}$ & 404 & 488 & 378 \\
ORP & $\mathrm{mV}$ & -219.1 & -123.5 & -210.2 \\
Temperature & ${ }^{\circ} \mathrm{C}$ & 30.1 & 30.1 & 28.2 \\
Fecal Coliforms & $\mathrm{MPN} / 100 \mathrm{~mL}$ & 8000 & 400 & 252 \\
Total Coliforms & $\mathrm{MPN} / 100 \mathrm{~mL}$ & 23000 & 1500 & \multicolumn{2}{c}{ Mountain } \\
Source of Water & & River & & \multicolumn{2}{c}{} \\
\hline
\end{tabular}

\section{Conclusions}

Based on the research conducted, the following conclusions can be drawn.

The radio-frequency plasma system generated active species that wereable to eliminate microorganisms in water (fecal coliforms and total coliforms).

In the optimum case, which was at afrequency of $3.7 \mathrm{MHz}$, the removal efficiency of fecal coliforms and total coliforms was $95.0 \%$ and $93.48 \%$ with the microorganisms death constantat 3.00 and $2.73 \mathrm{~h}^{-1}$, respectively.

Increasing the frequency increased the oxidation and reduction potential (ORP) of the water.

\section{Acknowledgments}

The author would like to thank DIKTI Indonesia who has supported this research through DIPA Kopertis X 2015 No. SP DIPA-023.04.1.673453/2015, in accordance with the Agreement on Implementation of Higher Education Competitive Research No. 14/Contract/010/KM/2015.

\section{References}

Desmiarti, R., Hazmi, A., Waldi, E. P., Ellyta, S., Yenni, T., \& Marhaeni, M. (2013). Performance of Dielectric Barrier Discharge for Degradation of Organic Compound and Removal of Microorganismss in Drinking Water, Proceedingsof the $3^{\text {rd }}$ International Symposium on Engineering, Energy and Environments-ISBN: 978-974-466-715-1, Bangkok.

El-Aragi, G. M. (2009). Drinking Water Analysis after Treatment by Corona Discharge. Plasma Physics and Nuclear Fusion Dept., Cairo, Egypt.

Hazmi, A., Desmiarti, R., Waldi, E. P., \& Darwison, D. (2013). Removal of Microorganismss in Drinking Water using Pulsed High Voltage. J. Engineering Technological Sciences, 45(1), 1-8. http://dx.doi.org/10.5614/j.eng.technol.sci.2013.45.1.1

Heesch, E. J. M., Pemen, A. J. M., Huijbrechts, A. H. J., van der Laan, P. C. T., Pissinski, K. J., Zanstra, G. J., \& de Jong, P. (2000). IEEE Trans. Plasma Sci., 28, 137. http://dx.doi.org/10.1109/27.842885

Joshi, A. A., Locke, B. R., Arce, P., \& Finney, W. C. (1995). Formation of HydroxylRadical, Hydrogen Peroxide and Aqueous Electrons by Pulsed Streamer CoronaDischarge in Aqueous Solution. J. Hazard Materials, 44.

Lukes, P. (2001). Water Treatment by Pulsed Streamer Corona Discharge, Institute of Chemical Technology, Prague.

Permenkes RI No.492/Menkes/Per/IV/2010 about Drinking Water Quality Standard 
Robinson, J. W, Ham, M., \& Balaster, A. N. (1973). Ultraviolet Radiation from Electrical Discharges in Water. J. Aplied Physics, 44. http://dx.doi.org/10.1063/1.1661943

Sun, B., Sato, M., \& Clements, J. S. (1997). Optical Study of Active Species Produced by a Pulsed Streamer Corona Discharge in Water. J. Electrostatics, 39. http://dx.doi.org/10.1016/s0304-3886(97)00002-8

Suslow, T. (2004). Oxidation-Reduction Potential (ORP) for Water Disinfection Monitoring, Control, and Dokumentation. ANR Publication 8149.

\section{Copyrights}

Copyright for this article is retained by the author(s), with first publication rights granted to the journal.

This is an open-access article distributed under the terms and conditions of the Creative Commons Attribution license (http://creativecommons.org/licenses/by/3.0/). 